\title{
PENYULUHAN PENTINGNYA PENINGKATAN STATUS IMUNOLOGI SEBAGAI UPAYA PENCEGAHAN TERJADINYA PENYAKIT KUSTA DI DAERAH ENDEMIS KUSTA
}

\section{EDUCATION OF THE IMPORTANCE OF IMMUNOLOGICAL STATUS IMPROVEMENT AS EFFORT TO PREVENT THE EVENT OF LEPROSY INFECTION IN LEPROSY ENDEMIS AREAS}

\author{
${ }^{1}$ Flora Ramona Sigit Prakoeswa. ${ }^{2}$ Erlita Puspitasari \\ ${ }^{1}$ Staff DepartemenIlmu Kesehatan Kulit dan Kelamin, Fakultas Kedokteran, Universitas \\ Muhammadiyah Surakarta \\ ${ }^{2}$ Analis Laboratorium Sentral Instalasi Patologi Klinik, RSUD. Dr. Soetomo Surabaya \\ Korespondensi: author 1. Alamat email: frsp291@ums.ac.id
}

\begin{abstract}
ABSTRAK
Jumlah kasus kusta di Indonesia sebanyak 16.825. Vaksinasi BCG memiliki efek proteksi terhadap individu sehat.efek proteksi vaksin BCG umumnya melindungi terhadap jenis kusta MB. Vaksinasi tersebut diketahui mampu memberikan proteksi lebih pada individu yang tinggal bersama dengan pasien kusta. Rendahnya vaksinasi BCG menyebabkan masih banyak orang yang tinggal dengan pasien kusta memiliki risiko yang tinggi untuk tertular. Diperlukan peningkatan status imunitas hospes, salah satunya adalah dengan meningkatkan cakupan vaksinasi BCG pada anak-anak, terutama yang tinggal di daerah endemis kusta. Penyuluhan ini diikuti oleh 10 peserta merupakan ibu dan anak penderita kusta dan keluarga sehat. Penyuluh dilakukan dengan konseling, diskusi, dan tanya-jawab.Untuk mengukur pemahaman sebelum dan setelah penyuluhan dilakukan “one group pre and post test design”. Data yang didapatkan dianalisis dengan uji Paired sample t test atau Wilcoxon menggunakan SPSS. Hasil analisis didapatkan rerata nilai pre test=46 dan post test=72. Hasil uji Wilcoxon didapatkan seluruh peserta mengalamI peningkatan pemahaman (nilai $p=0,004$ ). Kesimpulan dari penelitian ini terdapat peningkatan pemahaman ibu tentang pentingnya vaksin BCG untuk ibu dan anak sebagai upaya pencegahan penyakit kusta.
\end{abstract}

Kata Kunci: Kusta, Vaksin, Anak - Anak

\section{ABSTRACT}

The number of Leprosy in Indonesia is 16,825 cases. BCG vaccination has a protective effect on healthy individuals. The protective effect of BCG vaccine generally protects against MB leprosy. The vaccination is known to provide more protection for individuals living with leprosy. The low level of BCG vaccination causes many people who live with leprosy to have a high risk of contracting it. It is necessary to increase the immune status of the host, one of which is to increase the coverage of BCG vaccination in children, especially those living in leprosy endemic areas. Counseling was attended by 10 participants, who were mothers and children with leprosy and healthy families.Counseling was done with education, discussion, and question-answer. To measure understanding it is used "one group pre and post test design". The data obtained was analyzed by Paired T Test or Wilcoxon using SPSS. The average pretest $=46$ and posttest $=72$. Wilcoxon test showed that all participants experienced an increase in understanding ( $p$ value $=0.004)$. It is conclude that there is an increase in mother's understanding of the importance of the BCG vaccine for mothers and children as an effort to prevent leprosy

Keywords: Leprosy, Vaccines, Children 


\section{PENDAHULUAN}

Kusta merupakan suatu infeksi granulomatosa kronis yang disebabkan oleh infeksi Mycabacterium leprae (M. leprae). Transmisi infeksi dapat terjadi secara inhalasi, kontak kulit langsung, in utero, dan ingesti. Indonesia merupakan negara ketiga di dunia dengan jumlah kasus sebanyak 16.825 kasus dan angka kecacatan 6,82 orang per sejuta penduduk. Provinsi Jawa Timur merupakan satu satu provinsi di bagian barat Indonesia dengan angka beban kusta tinggi. Salah satu daerah yang memiliki kasus kusta yang tinggi yaitu Kabupaten Tuban. Jumlah penderita kusta di Kabupaten Tuban masih cenderung banyak dibandingkan daerah lain di Jawa Timur (WHO, 2016).

Berbagai faktor risiko yang dapat menyebabkan infeksi kusta, salah satunya adalah cakupan vaksinasi BCG perlu mendapatkan perhatian serius, karena hal-hal tersebut dapat mempengaruhi disregulasi imunitas hospes, sehingga menyebabkan kegagalan pemutusan transmisi infeksi kusta. Vaksinasi BCG dapat meningkatkan imunitas karena secara non spesifik bersifat memodulasi sistem imunitas, salah satunya terhadap infeksi kusta (Prabhu, 2015).

Vaksinasi BCG memiliki efek proteksi terhadap individu sehat. Berdasarkan penelian, efek proteksi vaksin BCG bervariasi antara 20 hingga 80 persen, dan umumnya melindungi terhadap jenis kusta MB. Efek proteksi vaksin BCG dipengaruhi oleh umur pemberian vaksin, jenis kelamin, dan riwayat kontak dengan penderita kusta. Pelaksanaan vaksinasi BCG kedua dapat meningkatkan efek protector BCG terhadap kasus kusta. Oleh karena itu, individu sehat yang tinggal bersama dengan pasien kusta diharapkan untuk melakukan revaksinasi atau vaksinasi kedua (de Oliveira and Diniz, 2016).

Hal ini juga ditegaskan pada penelitian lain yang menyatakan bahwa vaksinasi individu sehat tanpa gejala kusta penting untuk dilakukan karena vaksin BCG memiliki efek perlindungan tambahan (Gomes et al., 2019).

Meskipun telah melaksanakan program eliminasi kusta dengan menggunakan metode Multi Drug Treatment (MDT) dari WHO, namun hingga saat ini masih ditemukan kasus baru infeksi kusta. Hal tersebut diduga akibat kegagalan pemutusan mata rantai transmisi infeksi kusta, yang selain dipengaruhi oleh 
bakteri dan lingkungan, juga dipengaruhi oleh status imunitas individu. Diperlukan peningkatan status imunita, salah satunya adalah dengan meningkatkan vaksinasi BCG pada anak-anak, terutama yang tinggal di daerah endemis kusta.

Untuk mengatasi hal tersebut, maka ditawarkan suatu konsep solusi, yaitu memberikan penyuluhan mengenai pentingnya meningkatkan sistem imunitas, salah satunya dengan cara vaksinasi BCG, untuk mencegah berbagai penyakit infeksi, salah satunya penyakit kusta. Sasaran dari penyuluhan ini yaitu penduduk di Kecamatan Temandang, Kabupaten Tuban, yang merupakan salah satu daerah endemis kusta di daerah Tuban.

\section{TUJUAN DAN MANFAAT}

Penyuluhan ini dilaksanakan di Puskesmas Temandang, Kecamatan Temandang, Kabupaten Tuban merupakan salah satu daerah endemis kusta di daerah Tuban. Dilakukan penyuluhan mengenai pentingnya meningkatkan sistem imunitas, salah satunya dengan cara vaksinasi BCG, untuk mencegah berbagai penyakit infeksi, salah satunya penyakit kusta.

Tujuan jangka pendek diadakan penyuluhan ini untuk meningkatkan pengetahuan masyarakat tentang cara meningkatkan sistem imunitas sebagai upaya pencegahan penularan penyakit

kusta terutama pada anak - anak.

Tujuan jangka panjang diadakan penyuluhan ini untuk meningkatkan pengetahuan masyarakat terhadap pentingnya vaksinasi terutama vaksinasi BCG sebagai salah satu upaya untuk memutuskan rantai penularan kusta di wilayah endemis kusta.

\section{METODE PELAKSANAAN KEGIATAN}

Metode yang digunakan pada kegiatan pengabdian masyarakat ini adalah penyuluhan dan tanya jawab dengan masyarakat yang ada di Puskesmas Temandang Kabupaten Tuban.

Sasaran penyuluhan adalah para ibu memiliki keluarga atau anak penderita kusta dan ibu yang memiliki keluarga sehat (tidak menderita kusta). Populasi sasaran tersebut adalah ibu yang memiliki anak menderita kusta maupun ibu yang memiliki keluarga sehat di lingkungan Puskesmas Temandang.

$$
\text { Topik yang didiskusikan adalah }
$$
pentingnya vaksinasi, terutama vaksinasi BCG, karena dapat meningkatkan status imunitas seseorang, sehingga dapat mencegah terjadinya penyakit kusta.

Pemberian materi dilakukan dengan menggunakan metode dialog interaktif. Evaluasi 
terhadap hasil kegiatan dapat diukur melalui hasil sebelum dan sesudah dilakukan konseling, diskusi, dan tanya-jawab. Pengukuran tersebut merupakan jenis quasi experimental dengan rancangan penelitian "one group pre and post test design". Nilai yang didapatkan kemudian dianalisis menggunakan uji Paired sample t test dan uji alternatifnya yaitu uji Wilcoxon menggunakan software SPSS.

\section{HASIL DAN DISKUSI}

Kegiatan penyuluhan ini telah dilaksanakan pada hari Senin tanggal 2 Maret 2020 di Puskesmas Temandang, Kecamatan Temandang, Kabupaten Tuban.

Kegiatan ini diikuti oleh 10 orang ibuanak penderita kusta dan ibu-anak sehat di wilayah puskesmas Temandang.

Hasil konseling dan pemberian edukasi terhadap peserta, didapatkan nilai mean / rerata pre test sebesar 46 dengan nilai minimum 20 dan nilai maximum 80 , sedangkan nilai mean / rerata post test sebesar 72 dengan nilai minimum 60 dan nilai maximum 90.

Dari hasil pre test dan post test akan dilakukan analisa menggunakan uji normalitas data didapatkan nilai pre test $(\mathrm{p}=0,573)$ dan nilai post test $(\mathrm{p}=0,005)$ sehingga data kelompok post test dinyatakan tidak berdistribusi normal. Maka analisis data yang selanjutnya digunakan adalah uji non parametric wilcoxon.

Dari hasil uji wilcoxon terhadap pemberian materi pentingnya peningkatan pelayanan kesehatan didapatkan nilai seluruh peserta mendapatkan nilai post test lebih besar daripada pre test dengan nilai $\mathrm{p}=0,004$

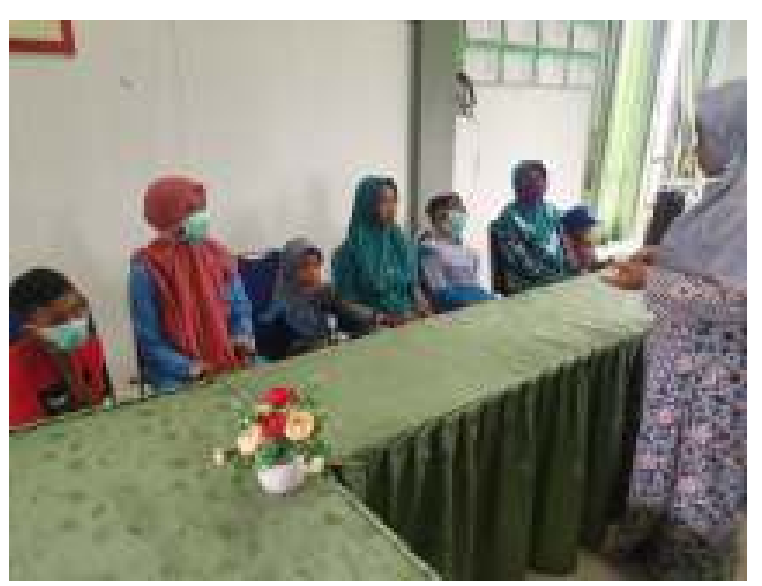

Gambar 1: Sesi Edukasi terhadap Peserta Penyuluhan

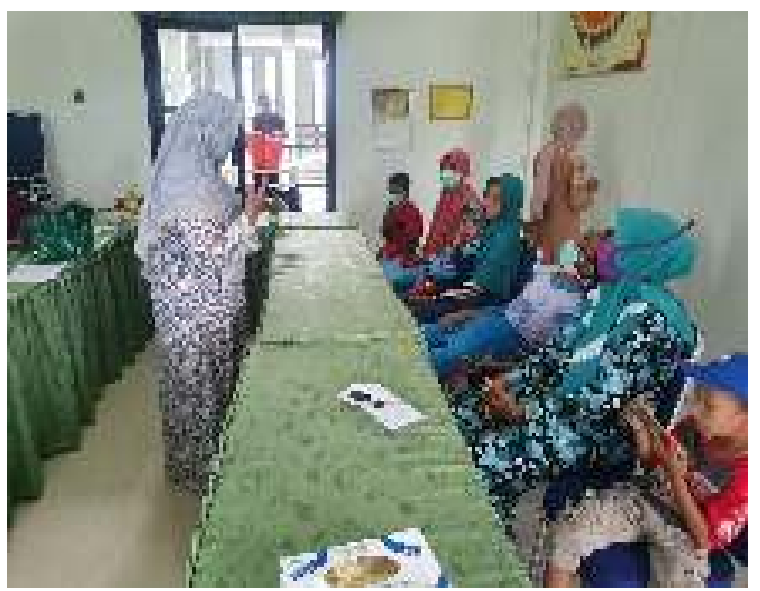

Gambar 2: Sesi Konseling 


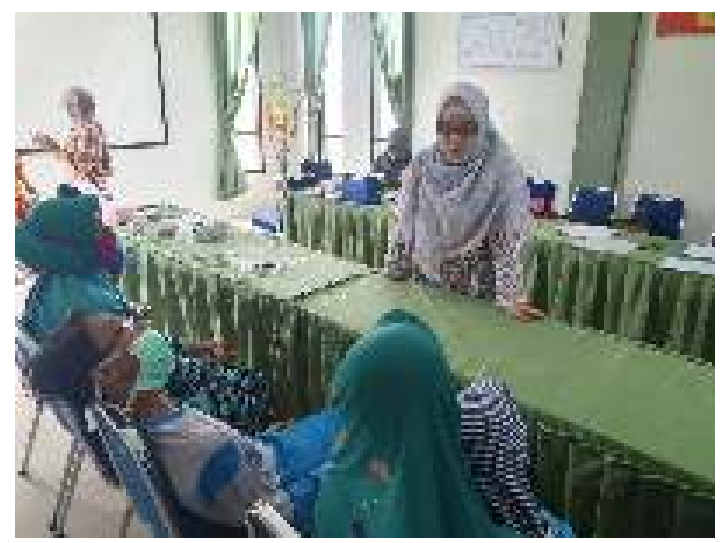

Gambar 3: Sesi Tanya Jawab

\section{HASIL DAN PEMBAHASAN}

Metode yang digunakan pada kegiatan pengabdian masyarakat ini adalah penyuluhan dan tanya jawab dengan masyarakat yang ada di Puskesmas Temandang Kabupaten Tuban pada hari Senin tanggal 2 Maret 2020. Topik yang didiskusikan adalah pentingnya vaksinasi, terutama vaksinasi BCG, karena dapat meningkatkan status imunitas seseorang, sehingga dapat mencegah terjadinya penyakit kusta.

Evaluasi terhadap hasil kegiatan dapat dilihat dari tanya jawab antara penyuluh dengan peserta setelah dilakukan konseling, informasi, dan edukasi. Tanya jawab berupa pengetahuan mengenai pentingnya mencegah penyakit kusta dengan cara meningkatkan imunitas, salah satunya adalah vaksinasi (termasuk BCG). Upaya peningkatan imunitas hospes sangatlah penting terutama bagi para warga yang tinggal di kawasan endemis seperti Kecamatan

Temandang. Berbagai riset baik nasional maupun internasional telah membuktikan cakupan efek proteksi yang cukup besar.

Pemberian materi dilakukan dengan menggunakan metode dialog interaktif. Pengabdian masyarakat ditutup dengan diskusi dan sesi tanya jawab yang diikuti oleh peserta dengan antusias.

Perlu dilakukan lebih banyak lagi penyuluhan, baik dari petugas kusta Puskesmas Temandang, maupun para kader Puskesmas Temandang, tentang pentingnya vaksinasi BCG, yang dapat meningkatkan respon imun seluler. Hal tersebut merupakan salah satu tindakan promotif dan preventif untuk membantu memutus transmisi infeksi kusta di daerah endemis.

\section{SIMPULAN DAN SARAN}

Perlu dilakukan lebih banyak lagi penyuluhan, baik dari petugas kusta Puskesmas Temandang, maupun para kader Puskesmas Temandang, tentang pentingnya vaksinasi BCG, yang dapat meningkatkan respon imun seluler. Hal tersebut merupakan salah satu tindakan promotif dan preventif untuk membantu memutus transmisi infeksi kusta di daerah 
endemis. Diharapkan masyarakat mampu berperan aktif dalam menghambat laju penyebaran penyakit kusta.

\section{UCAPAN TERIMAKASIH}

Penyuluhan ini dilaksanakan atas kerjasama Departemen Ilmu Kesehatan Kulit dan Kelamin Fakultas Kedokteran Universitas Muhammadiyah Surakarta dengan Dinas Kesehatan Kabupaten Tuban. Kami ucapkan teriimakasih kepada pihak-pihak yang telah membantu dalam kegiatan pengabdian masyarakat ini

\section{DAFTAR PUSTAKA}

De Oliviera, M. B. B. and Diniz, L.M (2016). Leprosy among children under 15 years of age: Literature review, Anais Brasileiros de
Dermatologia, 91(2), pp. 196-203.

Gomes, R. R., Antunes, D. E., dos Santos, D. F., Sabino, E. F. P., Oliveira, D. B., \& Goulart, I. M. B. (2019). BCG vaccine and leprosy household contacts: Protective effect and probability to becoming sick during followup. Vaccine, 37(43), 6510-6517.

Joshi PL, 2016. Epidemiology in Leprosy. En: IAL Textbook o fLeprosy. Edisi kedua, pp. 33-44.

PrabhuDas M, Bönnëy E, Caron K, Dey S,Erlëbacher A, Fazleabas A, Fisher S, Golos T, Matzuk M, McCune JM, Mor G, Schulz L, Soares M, Spencer T, Stroininger J, Way SS, Yoshinaga K, 2015. Immune mechanism at the maternal interface: perspectives and challenges, Nature in immunology, vol.16, no 4, pp. 328-334.

Vieira, M.C.A.., et a (2018). Leprosy in children under 15 years of age in Brazil: A systematic review of the literature, PLos Neglected Tropical Disease, 12(10), pp. 1-13.

WHO. 2016. Global Leprosy Update: time for action, accountability, and Inclussion. 